\begin{abstract}
Understanding spawning behavior of commercial fish populations provides a basis for making management decisions related to these stocks. Archival tags can be used to define spawning behavior when depth-specific movements are involved. Spawning behavior of Greenland halibut (Reinhardtius hippoglossoides) in the eastern Bering Sea and the Aleutian Islands was inferred from archival tag data. The predominant period of identified spawning activity, based on abrupt vertical rises of females, occurred in January and February, and females reached apexes in their upward movement (spawning rises) at depths of approximately $200-350 \mathrm{~m}$ below the surface, indicating that the release of eggs could occur at depths shallower than previously assumed. Females had a single spawning rise annually, a result supporting the notion that this species is a total (single-batch) spawner. Male Greenland halibut exhibited spawning behavior, rises to shallower depths one or more times, for an average of $20 \mathrm{~d}$. For large female Greenland halibut (>80 cm in fork length), spawning rises occurred in consecutive years, indicating that, despite oocyte development taking more than 1 year, spawning occurs annually. Inferring spawning behavior by using data collected with archival tags can aid in understanding the maturity of Greenland halibut.
\end{abstract}

Manuscript submitted 6 July 2021. Manuscript accepted 7 February 2022. Fish. Bull. 120:55-67 (2022).

Online publication date: 16 February 2022. doi: 10.7755/FB.120.1.5

The views and opinions expressed or implied in this article are those of the author (or authors) and do not necessarily reflect the position of the National Marine Fisheries Service, NOAA.

\title{
Characterizing spawning behavior of Greenland halibut (Reinhardtius hippoglossoides) in the eastern Bering Sea and Aleutian Islands
}

\author{
Kevin A. Siwicke (contact author) ${ }^{1}$ \\ Andrew C. Seitz ${ }^{2}$ \\ Cara J. Rodgveller ${ }^{1}$ \\ Katy B. Echave ${ }^{1}$ \\ Email address for contact author: kevin.siwicke@noaa.gov \\ 1 Auke Bay Laboratories \\ Alaska Fisheries Science Center \\ National Marine Fisheries Service, NOAA \\ 17109 Point Lena Loop Road \\ Juneau, Alaska 99801 \\ 2 Department of Fisheries \\ College of Fisheries and Ocean Sciences \\ University of Alaska Fairbanks \\ P.O. Box 757220 \\ Fairbanks, Alaska 99775
}

Archival tags can be attached to fish to collect environmental data, usually temperature and pressure (converted to depth) at a minimum, and individual events characterized by changes in such environmental conditions can be identified with data from recovered tags (Wilmers et al., 2015). The battery life of archival tags (also known as data storage tags) allows data to be recorded for up to several years, and the data therefore can be used to assess depthor temperature-specific behavior, such as spawning, that occurs over annual cycles. Knowledge about reproductive traits (fecundity, maturity, and timing or location of spawning) of a fish stock is important for estimating the stock's reproductive potential (Murawski et al., 2001; Wright and Trippel, 2009; Cooper et al., 2013). Population estimates, mean weights by age, and maturity ogives (often derived from histological, macroscopic, or laboratorybased studies) are used for estimating stock reproductive potential in the form of spawning stock biomass (Marshall, 2009), although this measure is susceptible to size- and age-dependent effects (Trippel, 1999; Cooper et al., 2013). Misinterpretation of a reproductive trait can therefore lead to incorrect or biased estimation of stock reproductive potential.

Data from archival tags have been used to determine spawning behavior, allowing the unobservable to be "seen" (Seitz et al., 2005; Loher and Seitz, 2008; Murphy et al., 2017; Le Bris et al., 2018); therefore, this method can provide deductions of spawning behavior. In archival tag records, abrupt movements of fish to shallower depths are identified as spawning rises. These ascents are thought to be analogous to spawning behavior of shallow-water flatfish species that has been directly observed when they swim off the bottom to spawn (e.g., Manabe and Shinomiya, 2001). The rhythmic behavior of batch spawning, which refers to the behavior of species that spawn a batch of eggs 
every few days over a period of weeks, can be identified in archival tag data. Spawning rises have been inferred for 2 batch-spawning species, the Pacific halibut (Hippoglossus stenolepis) and the Atlantic halibut (H. hippoglossus), by using archival tags.

Although female halibut are expected to have multiple spawning rises separated by at least 2 days, during which time batches of ova are hydrated (St-Pierre, 1984; Finn et al., 2002), male halibut are limited only by mating opportunities, resulting in a pattern in which spawning rises are more variable and frequent. In previous studies, data from archival tags was used to reveal spawning rises in females (e.g., one Pacific halibut rose 7 times in 3 weeks), and the authors also hypothesized that male spawning behavior had a more frequent and variable rise pattern, although sex was not identified (Seitz et al., 2005; Loher and Seitz, 2008). Similar patterns of spawning behavior of Atlantic halibut have been discerned in archival tag data with sex determined: female spawning has been characterized by 4-6 rises over a period of $10-17 \mathrm{~d}$, and males have been reported to have more sporadic rises over a protracted period (Murphy et al., 2017).

The Greenland halibut (Reinhardtius hippoglossoides), also known as the Greenland turbot, is a close relative to the Pacific and Atlantic halibut (Vinnikov et al., 2018) and is a commercially important deepwater flatfish species found in the North Atlantic, North Pacific, and Arctic Oceans. This species can reach a size of up to $120 \mathrm{~cm}$ in fork length (FL), and females become mature at 60-70 cm FL (Cooper et al., 2007). Adult Greenland halibut have been found at depths greater than $1500 \mathrm{~m}$ and in waters with temperatures from $0^{\circ} \mathrm{C}$ to $4^{\circ} \mathrm{C}$ (Peklova et al., 2012; Siwicke and Coutré, 2020). Archival tag data from other studies indicate that Greenland halibut exhibit much vertical activity (Boje et al., 2014; Siwicke and Coutré, 2020) and can spend up to a quarter of their time in the pelagic environment (Albert et al., 2012). This species carries 2 cohorts of vitellogenic oocytes that are easily separated by their relative diameters, large and small (Kennedy et al., 2011). Interpretations of this trait for Greenland halibut have evolved (e.g., Fedorov, 1968; Rideout et al., 1999; Gundersen et al., 2000; Junquera et al., 2003), but the most recent understanding is that oocytes take more than 1 year to complete vitellogenesis, 2 cohorts of oocytes are present, with the large cohort spawned in the current year and the small cohort spawned in the following year (Kennedy et al., 2011; Rideout et al., 2012). This reproductive trait has been found in other coldwater fish species (e.g., Everson, 1994).

One basic aspect of reproduction of Greenland halibut that is uncertain is whether females are batch or total spawners (Stene et al., 1999; Kennedy et al., 2009). Female Greenland halibut are often caught in a prespawning or postspawning stage, and ripe or running females are rare. A single running female readily released all of her ovulated eggs when artificially spawned (Stene et al., 1999), and another female Greenland halibut released a single batch of eggs over the course of a year in a laboratory (Domínguez-Petit et al., 2013); both of these outcomes indicate that the species is a total spawner. When ripe females have been caught during longline surveys near Greenland, all oocytes were hydrated (although it was not stated whether this finding was only for the large cohort of oocytes), indicating that Greenland halibut spawn a single batch in the wild (Gundersen et al., 2013). The term total spawner can be used to describe a Greenland halibut that releases eggs once in a year (Murua and Saborido-Rey, 2003).

Knowledge of the timing and location (spatial and depth) of spawning is important for understanding stock structure and dynamics (i.e., egg-larval drift and migrations), basic information used in stock assessment and fisheries management. For Greenland halibut, these characteristics appear to vary by region and are poorly understood. Spawning activity of Greenland halibut inferred from gonadosomatic index analyses indicates that spawning occurs along the continental slope from November through January (Albert et al., 2001). Larval distributions indicate that this species spawns at depths between 800 and $1000 \mathrm{~m}$ from December through April (Smidt, 1969). Serebryakov et al. (1992) determined that spawning occurs at depths between 1000 and $1500 \mathrm{~m}$, using the presence of larvae at these depths. The majority of the spawning of Greenland halibut in the eastern Bering Sea is assumed to occur deep on the slope (Alton et al., 1988) and between October and March (October-December, Musienko, 1970; February-March, Bulatov, 1983; and December-January, Sohn et al., 2010). Archival tag data from another study indicate that this stock does move to deeper waters along the continental slope during winter, a shift that is presumed to be from feeding to spawning grounds (Siwicke and Coutré, 2020). In captivity, spawning has occurred mostly from January through March in consecutive years (Domínguez-Petit et al., 2013). It is difficult to know what effect the laboratory conditions had on reproduction.

The depth at which eggs are released influences egg dispersal (currents) and development time (temperature). Both development of the embryo and timing of hatching are dependent upon the surrounding water temperature (Domínguez-Petit et al., 2013). It is believed that, in the Bering Sea, spawning occurs in deep submarine canyons and eggs are advected up and onto the nursery grounds of the continental shelf (Sohn et al., 2010; Duffy-Anderson et al., 2013). The accuracy of these assumptions will influence the accuracy of estimated development time and hatch date. For example, if an egg was in water that is warmer than assumed, the development time would be shortened, the back-calculated hatch date would be later in the year, and the time for egg dispersal by currents would be shortened. Additionally, if the depth at which eggs are released is incorrect and if current speed varies by depth, estimates of dispersal distance of eggs will also be affected.

If spawning is identifiable in archival tag data, this method can be useful for corroborating estimates of size at maturity and other characteristics from stock assessments. Currently, the assessment of the Bering Sea-Aleutian Islands (BSAI) Greenland halibut stock uses a logistic relationship of maturity and size, with the length at $50 \%$ maturity $\left(L_{50}\right)$ set at $60 \mathrm{~cm}(2 \%$ at $50 \mathrm{~cm}$ and $98 \%$ at $70 \mathrm{~cm})$ 
following D'yakov (1982). Results of later work indicate a larger $L_{50}$, but the study had limited sample sizes and its $L_{50}$ has not been adopted for stock assessments (Cooper et al., 2007). Following the acknowledgment that there are 2 separate cohorts of oocytes simultaneously developing (Kennedy et al., 2011), the large cohort to be spawned this year and the small cohort to be spawned in the following year, maturity ogives of 2 different stocks of Greenland halibut have been reanalyzed with the small cohort of oocytes considered to be immature. In analysis of archival tag data from work in eastern Greenland, reclassifying females as having only developing oocytes (i.e., only the first cohort of oocytes that will not be mature in 12 months) led to a decrease in the estimate of spawning stock biomass of an average of $56 \%$, with associated declines in total egg production; notably, estimates of $L_{50}$ increased from 63.8 to $80.2 \mathrm{~cm}$ FL for one stock and from 61.2 to $74.1 \mathrm{~cm} \mathrm{FL}$ for the other (Kennedy et al., 2014). Lengths of tagged female Greenland halibut that exhibited spawning behavior could be used to inform decisions regarding maintaining or reexamining the $L_{50}$ used in stock assessments.

Our objective was to assess whether we could identify spawning behavior in data from archival tags implanted in Greenland halibut, and if so, to characterize it. If spawning behavior can be detected in tag data, we could infer and clarify several aspects of the reproduction of Greenland halibut in the BSAI: 1) the timing of spawning, 2 ) the depth at which eggs are released, 3) the frequency of spawning in a year (i.e., batch or total), and 4) whether individual females spawn in consecutive years.

\section{Materials and methods}

\section{Data collection}

Archival tags have been implanted in Greenland halibut since 2003 during the longline surveys conducted by the NOAA Alaska Fisheries Science Center in the BSAI region. Briefly, longlines are set along the continental slope in the BSAI, and Greenland halibut captured on predetermined hooks that are in good condition and longer than $50 \mathrm{~cm}$ FL are placed in a tank with flowing seawater prior to tagging. The minimum length threshold of $50 \mathrm{~cm}$ FL meant that tagged fish were likely to be mature (Cooper et al., 2007).

A total of 297 Greenland halibut had Lotek ${ }^{1}$ archival tags (Lotek Wireless Inc., Newmarket, Canada) internally implanted, with the specific tag model varying by year (2003: model LTD-1250; 2005-2008: model LTD-1300; 2011: model LAT-2800). Tags recorded temperature and pressure (converted to depth) at regular sampling frequencies between 1 and $15 \mathrm{~min}$, depending on the year of deployment. The tag, surgical site, and tools were disinfected by using 3\% Betadine, tags were inserted into

\footnotetext{
${ }^{1}$ Mention of trade names or commercial companies is for identification purposes only and does not imply endorsement by the National Marine Fisheries Service, NOAA.
}

the body cavity through a 2 -cm-long incision made in the abdominal wall of the right side of the fish, and the incision was closed with surgical staples. Fish were released in close proximity to their site of capture, and tags were recovered by commercial fishing vessels (trawl or longline). Size (FL) of Greenland halibut was recorded at release, and FL, weight, and sex (determined with visual inspection of gonads) were recorded for some but not all tagged fish that were recaptured.

\section{Identified spawning behavior}

Archival tag data, specifically depths converted from pressure records, from tags implanted in Greenland halibut were used to identify and characterize the timing, depths, and frequency of spawning behavior for this species. Depth data were analyzed to find spawning behavior defined as "abrupt spikes," which consist of rapid ascents to an apex followed by rapid descents, as outlined in Seitz et al. (2005), Loher and Seitz (2008), and Murphy et al. (2017). We first filtered each fish's depth record to the most extreme $0.1 \%$ of ascents and descents to focus on a smaller more manageable subset (Suppl. Fig. 1). Larger percentages $(>1 \%$ and $>5 \%$ ) were explored but did not add any insight into spawning behavior. In addition, spawning rises are expected to occur over periods of only hours to days in an individual's year. When an extreme ascent closely preceded an extreme descent, the entire depth record for that day was further analyzed. Greenland halibut may use more of the water column than Atlantic and Pacific halibut (e.g., Albert et al., 2012), and rapid ascents and descents could be related to other behaviors that are not related to spawning. Often, extreme ascents or descents were identified in isolation, or a descent was followed by an ascent; however, given our assumption that a spawning rise is a rapid ascent from the seafloor to spawn midwater followed by a rapid return to the seafloor, these other events were not further analyzed (Suppl. Fig. 2). Among flagged events, sex-specific similarities aided in deciding which events to classify as spawning behavior (e.g., Murphy et al., 2017).

The start date, time of day, and initial depth were identified for the time directly before the initiation of the first spawning rise, and the end date, time of day, and final depth were recorded at the completion of the last spawning rise, such that multiple rises would be encompassed in this period. The exact times when a rise was initiated and completed were determined on a case-by-case basis, by qualitatively and visually assessing the depth profile preceding and following rises to best capture the individual behavior. The time of day at which an individual reached a minimum depth during spawning rises (i.e., the apex) was noted to assess whether there was a daily preferred time of spawning. Additionally, the maximum ascent and descent rate (meters per minute) occurring between the start and end times of a spawning event were also compared.

Spawning rises of female Greenland halibut were further investigated to discern whether they occurred 
multiple times or singularly within a year and whether they occurred in consecutive years. We anticipated finding multiple rises over the course of several days if batch spawning was occurring, as has been observed for Atlantic halibut (Murphy et al., 2017). A singular rise would indicate total spawning, or a single batch, as has been observed for captive Greenland halibut (Domínguez-Petit et al., 2013). Evidence of female Greenland halibut having spawning rises in consecutive years (from tagged fish that were at liberty for more than 1 winter) would indicate that spawning can occur every year despite oocyte development requiring a period of 2 years (Kennedy et al., 2011; Rideout et al., 2012). Such a reproductive scenario is unusual but still considered that of a total spawner. In the first year, a female produces oocytes, but no spawning occurs. In the second and subsequent years, 2 cohorts of oocytes are present in the ovaries (a small cohort, with less than 1 year of development, and a large cohort, with more than 1 year but less than 2 years of development); the large cohort is spawned in the second year, and spawning can occur each subsequent year.

The depths of the apexes of spawning rises for female Greenland halibut were carefully estimated because these depths were assumed to be the depths at which eggs were released. Similar assumptions have been made for the family Pleuronectidae because the only observed flatfish spawning behavior has included release of eggs at the apex of spawning rises (see review in Seitz et al., 2005). Estimation of the apex depth varied with the sampling frequency of the tag, given that an increase in sampling frequency increases the probability of capturing the actual apex. When the sampling interval was 1 min, the minimum depth achieved was the estimate of the apex. For sampling intervals greater than 1 min (i.e., 4 and $15 \mathrm{~min}$ ), depths were interpolated to a 1-min frequency by using the intersection of 2 simple linear models, the ascent and the descent. The estimated apex was determined by setting these equations equal to each other (i.e., the depth at which the 2 lines cross). This interpolation was not intended to exactly replicate the trajectory of these fish, although it was expected to approximate the depth of the apex better than taking the observed minimum depth from a low-frequency sampling interval (Suppl. Figs. 3 and 4). Additional information related to inferring and interpolating spawning rises is available in Supplementary Materials.

\section{Results}

As of 2020, 22 of the $297(7.4 \%)$ Greenland halibut implanted with archival tags have been recovered and returned to the Alaska Fisheries Science Center. The tags from 13 of these fish ( 6 males, 5 females, and 2 fish of undetermined sex) provided usable data through at least one presumed spawning period, October-March, with 6 fish at liberty for multiple years (Suppl. Table). Spawning behavior was identified and characterized for 11 tagged Greenland halibut ( 6 males, 3 females, and 2 fish of undetermined sex). Release and recapture locations were across the BSAI region (Fig. 1).

Extreme ascents and descents of tagged fish occurred throughout the year, but the top $0.1 \%$ of vertical movements

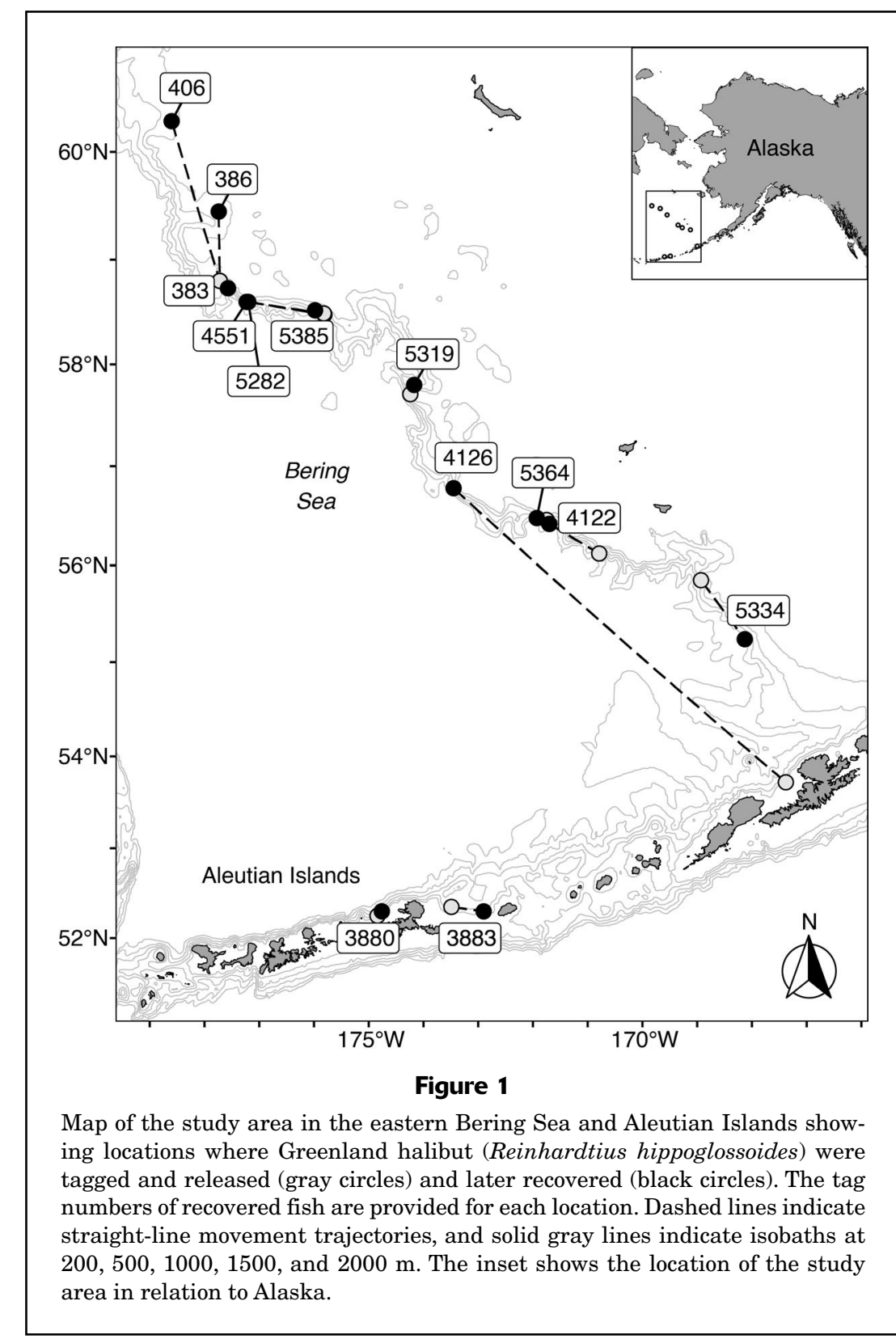


generally coincided with data for males and females during January and February (Suppl. Fig. 1). Upon closer inspection, numerous spawning rises were identified, with 2 distinct patterns that mostly varied with sex: 1) a singular rise with a sharp ascent and descent for females and 2) more sporadic, often prolonged periods of rapid ascents and descents for males (Fig. 2). Maximum ascent rates ranged from 8.1 to $31.0 \mathrm{~m} / \mathrm{min}$, with maximum descent rates between 10.5 and $28.0 \mathrm{~m} / \mathrm{min}$ (Table 1 ).

\section{Females}

Three of the 5 female Greenland halibut had spawning rises and were $84-88 \mathrm{~cm} \mathrm{FL}$ at release; the 2 that did not were 68 and $71 \mathrm{~cm} \mathrm{FL}$ at release. The females that exhibited spawning behavior did so for all winters at liberty (Fig. 3). The dates of the singular rises by females ranged from 12 January to 12 February, with individuals having almost exactly a 1-year interval between rises (Table 1). Individual females initiated spawning rises from relatively similar depths across years (Table 1). The shallowest depths recorded for females at the apexes of their rises ranged from 229 to $420 \mathrm{~m}$, and the narrower estimates from interpolation were between 217 and $326 \mathrm{~m}$ (Fig. 4). The elapsed time of singular rises ranged from 0.5 to $2.5 \mathrm{~h}$. The duration of spawning rises generally lengthened with increases in the bottom depth at which ascents were initiated. No consistent pattern for the time of day at which fish reached an apex was observed (Table 1). Recorded temperatures were 2.8$3.8^{\circ} \mathrm{C}$ before spawning rises and $3.7-4.1^{\circ} \mathrm{C}$ at the apex of ascents. Because the tags were internally implanted and the ascents and descents were steep, tag sensors were unlikely to have adjusted to the ambient water temperature and the actual apex temperature was likely to have been warmer than tag data indicate. The movement of one fish (tag no. 386, with no spawning rises identified) is unique in that, during the winter, the fish moved to relatively shallow water, presumably to the continental shelf.

\section{Males}

All 6 male Greenland halibut exhibited spawning behavior during at least 1 winter for an average of $20 \mathrm{~d}$. Four of these males were at liberty only for the winter of 2003-2004; for these males, spawning behavior occurred for 27-41 d between 2 January and 13 February (Table 1). One male was at liberty for 3 consecutive winters, and the data from its tag provides evidence of spawning behavior occurring in each year. In the third winter, this fish inhabited waters that were substantially deeper (depths of $\sim 1200 \mathrm{~m}$ ) than in the previous 2 winters (depths of $600-700 \mathrm{~m}$ ), and it had a single, brief spawning rise to a depth of $508 \mathrm{~m}$ on
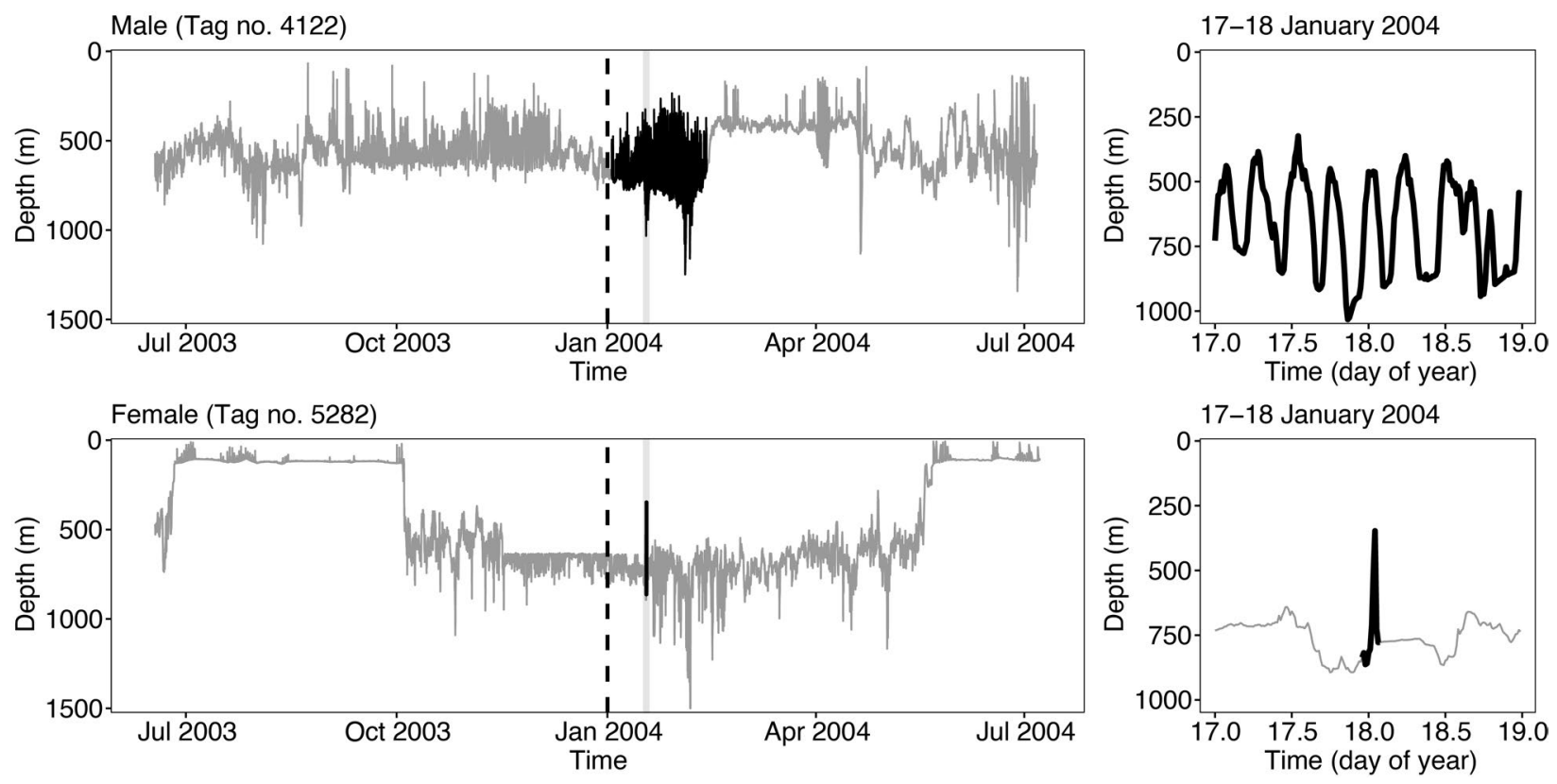

Figure 2

Examples of 1 year of depth data for a male (top left) and female (bottom left) Greenland halibut (Reinhardtius hippoglossoides) tagged and released in June 2003 in the eastern Bering Sea. The vertical black dashed line in each left panel indicates the change in year from 2003 to 2004, and the black parts of lines indicate the timing of putative spawning. The right panels focus on depth data for $2 \mathrm{~d}$ (17 and 18 January 2004), and this period is highlighted by a vertical grey bar in each left panel, with the black parts of lines again indicating the timing of associated spawning. 


\section{Table 1}

Summary of data on putative spawning of Greenland halibut (Reinhardtius hippoglossoides) tagged in 2003, 2005, 2008, or 2011 and recaptured in the eastern Bering Sea and Aleutian Islands. Data collected include the tag number, year of spawning observation, sex of fish, day of the year spawning initiated $\left(D_{i}\right)$, depth preceding minimum depth during spawning $\left(Z_{\mathrm{i}}\right)$, shallowest depth during spawning $\left(\mathrm{Z}_{\min }\right)$, time at shallowest depth during spawning $\left(\right.$ Time $\left.e_{\text {min }}\right)$, depth following minimum depth during spawning $\left(Z_{f}\right)$, day of year spawning ended $\left(D_{f}\right)$, elapsed time spawning occurred (Dur.), maximum spawning ascent rate $\left(\mathrm{Asc}_{\max }\right)$, and maximum spawning descent rate (Des $\mathrm{max}_{\max }$ ). Sex is presented for females (F), males (M), and those fish for which sex is undetermined (U), with a subscript indicating which sex it is likely to be on the basis of the archival tag data. Additional information on each tagged fish can be found in Supplementary Table.

\begin{tabular}{|c|c|c|c|c|c|c|c|c|c|c|c|}
\hline Tag no. & Year & Sex & $\mathrm{D}_{\mathrm{i}}$ & $\mathrm{Z}_{\mathrm{i}}(\mathrm{m})$ & $\mathrm{Z}_{\min }(\mathrm{m})$ & Time $_{\text {min }}$ & $\mathrm{Z}_{\mathrm{f}}(\mathrm{m})$ & $D_{f}$ & Dur. (d) & $\begin{array}{l}\mathrm{Asc}_{\max } \\
(\mathrm{m} / \mathrm{min})\end{array}$ & $\begin{array}{c}\operatorname{Des}_{\max } \\
(\mathrm{m} / \mathrm{min})\end{array}$ \\
\hline 5282 & 2004 & $\mathrm{~F}$ & 18 & 859 & 347 & 0100 & 777 & 18 & 0.08 & 13.6 & 25.2 \\
\hline 5282 & 2005 & $\mathrm{~F}$ & 19 & 972 & 420 & 0800 & 895 & 19 & 0.10 & 19.7 & 25.6 \\
\hline 5282 & 2006 & $\mathrm{~F}$ & 17 & 886 & 343 & 1115 & 919 & 17 & 0.07 & 17.0 & 16.4 \\
\hline 4551 & 2006 & $\mathrm{~F}$ & 12 & 716 & 240 & 0132 & 716 & 12 & 0.05 & 19.8 & 23.3 \\
\hline 4551 & 2007 & $\mathrm{~F}$ & 13 & 917 & 254 & 0452 & 979 & 13 & 0.08 & 18.9 & 20.4 \\
\hline 383 & 2012 & $\mathrm{~F}$ & 43 & 619 & 229 & 2220 & 617 & 43 & 0.04 & 31.0 & 24.5 \\
\hline 383 & 2013 & $\mathrm{~F}$ & 26 & 526 & 240 & 1435 & 482 & 26 & 0.02 & 29.5 & 28.0 \\
\hline 383 & 2014 & $\mathrm{~F}$ & 25 & 527 & 230 & 1125 & 591 & 25 & 0.03 & 26.5 & 26.5 \\
\hline 4122 & 2004 & $\mathrm{M}$ & 2 & 824 & 234 & 0345 & 820 & 44 & 41.43 & 15.2 & 10.5 \\
\hline 4126 & 2004 & M & 10 & 1098 & 328 & 0430 & 1243 & 43 & 32.90 & 17.1 & 20.6 \\
\hline 5319 & 2004 & M & 12 & 1435 & 239 & 0300 & $1438+$ & 40 & 27.48 & 15.6 & 15.7 \\
\hline 5364 & 2004 & $\mathrm{M}$ & 2 & $1489+$ & 360 & 2130 & $1489+$ & 40 & 37.82 & 17.2 & 17.9 \\
\hline 5385 & 2004 & $\mathrm{M}$ & 6 & 689 & 221 & 0445 & 665 & 22 & 16.75 & 17.2 & 20.1 \\
\hline 5385 & 2005 & $\mathrm{M}$ & 10 & 750 & 268 & 0245 & 708 & 34 & 23.73 & 15.8 & 11.9 \\
\hline 5385 & 2006 & M & 8 & 1232 & 508 & 2300 & 1021 & 9 & 0.18 & 8.1 & 11.9 \\
\hline 3883 & 2010 & M & 6 & 664 & 253 & 1716 & 670 & 6 & 0.07 & 24.0 & 14.3 \\
\hline 5334 & 2004 & $\mathrm{U}_{\mathrm{M}}$ & 2 & 956 & 266 & 0000 & 968 & 32 & 30.42 & 15.2 & 11.7 \\
\hline 3880 & 2009 & $\mathrm{U}_{\mathrm{F}}$ & 11 & 1520 & 310 & 1608 & 1361 & 11 & 0.20 & 17.5 & 20.3 \\
\hline
\end{tabular}

8 January (Fig. 5). Another male, released and recaptured in the Aleutian Islands (tag no. 3883; Fig. 1), was at liberty for 2 winters, with tag data indicating that no spawning behavior occurred in the first winter and that a single spawning rise occurred in the second winter on 6 January (Table 1, Fig. 5). The shallowest recorded depths for males during spawning rises ranged from 221 to $508 \mathrm{~m}$ (Table 1). No effort was made to better estimate apexes when the sampling interval was greater than 1 min because males often had more staggered ascents and descents and lingered at shallow depths $(<500 \mathrm{~m})$, and as a result, the apexes of their ascents were not easily interpolated with linear methods. Temperature at the apexes ranged from $3.6^{\circ} \mathrm{C}$ to $4.3^{\circ} \mathrm{C}$. Time of day varied for spawning rises (Table 1), and individuals had varying patterns in frequency and duration of their ascents (Fig. 5).

\section{Fish of undetermined sex}

For 2 fish with usable data, sex could not be determined at recapture, but spawning behavior was identified for both. One of these fish (tag no. 3880) was released and recaptured in the Aleutian Islands and exhibited behavior consistent with a singular spawning rise of a female; this distinction is not definitive because males sometimes had only a single ascent evident in their tag data. The release and recapture sizes of this fish were recorded as $94 \mathrm{~cm} \mathrm{FL}$, and sexually dimorphic size differences indicate that this fish is likely a female because females typically reach greater sizes than males (Bryan et al., 2018). The singular spawning rise of this fish occurred on 11 January, beginning at a depth of $1520 \mathrm{~m}$ and reaching a minimum depth of $310 \mathrm{~m}$, before returning to a depth of $1361 \mathrm{~m}$ (Table 1, Fig. 6). The second fish (tag no. 5334) had a size of $69 \mathrm{~cm}$ FL recorded at release (no FL was recorded at recapture). This fish exhibited behavior with repetitive spawning rises between 2 January and 1 February (Table 1, Fig. 6), reaching a minimum depth of $266 \mathrm{~m}$ during this time. This spawning behavior was similar to that of known males in this study.

\section{Discussion}

Field-based tagging research on Greenland halibut can be used to infer previously unobserved reproductive behavior and is an important complement to lab-based research. The research of this study provides information for identification of spawning rises of Greenland halibut. Further, results of this work indicate distinct spawning behaviors for each sex: females have a single spawning rise, and males often make repetitive ascents over a protracted period. Findings from analysis of archival tag data 


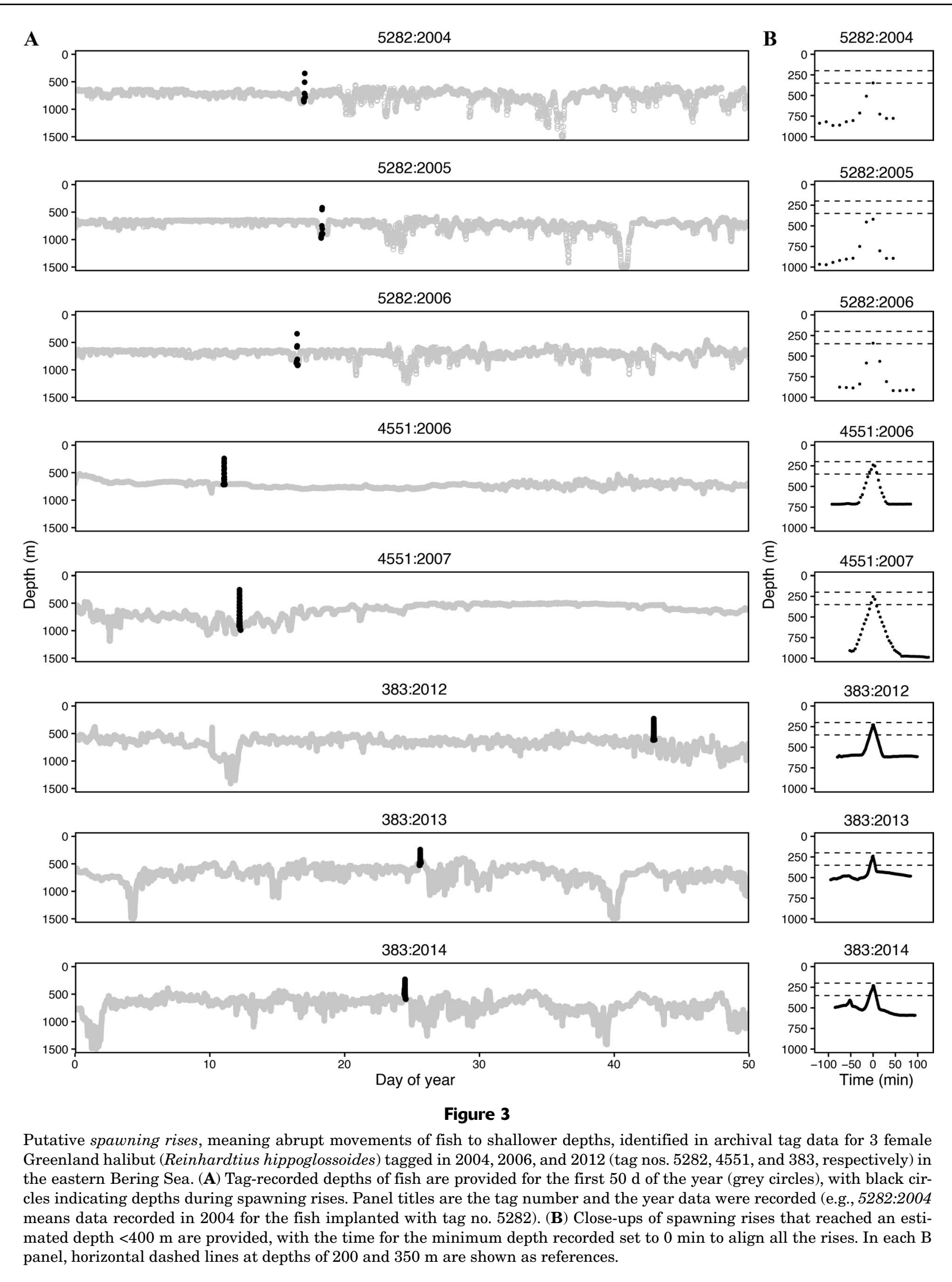




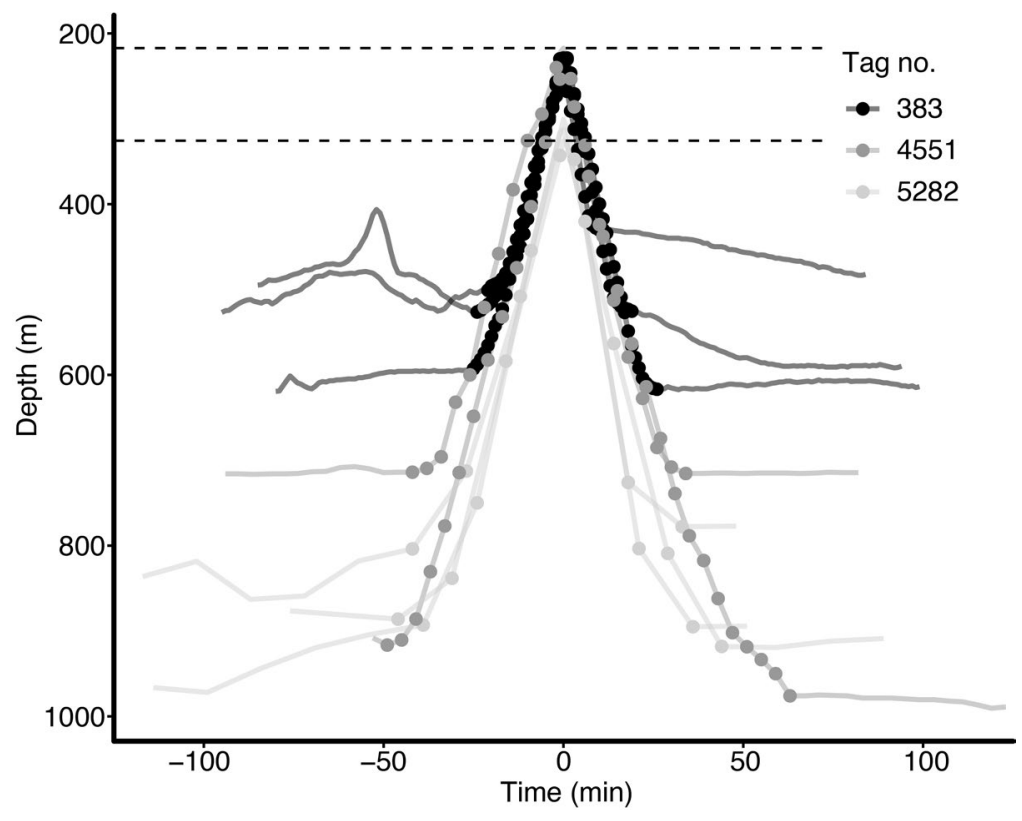

Figure 4

Putative spawning rises, meaning abrupt movements of fish to shallower depths, identified in archival tag data for 3 female Greenland halibut (Reinhardtius hippoglossoides) tagged in 2004, 2006, and 2012 (tag nos. 5282, 4551, and 383 , respectively) in the eastern Bering Sea. Black and gray circles indicate depths recorded during spawning rises. Lines indicate depth profiles before, during, and after spawning rises and apexes of those rises (apexes were estimated by using simple linear models with data from tags with sampling intervals $>1 \mathrm{~min}$ ). The time at the apex of the rise has been set to $0 \mathrm{~min}$, and horizontal dashed lines indicate the minimum and maximum depths estimated for the apex of putative spawning rises (217-326 m).

forward for lumpfish (Cyclopterus lumpus), another species with this trait (Kennedy and Ólafsson, 2019). Consistency in the timing of spawning for the BSAI Greenland halibut stock indicates that spawn timing for populations in other regions should be reexamined. Considering that the 2-year oocyte development of this species was not well understood until recently (Kennedy et al., 2011; Rideout et al., 2012), it is possible that misspecification of maturity could lead to incorrect conclusions across the entire range of the Greenland halibut.

Temperature and currents may play a role in regulating development time and dispersal of the eggs and larvae of Greenland halibut. Greenland halibut are known to overwinter at depths $>600 \mathrm{~m}$ (Siwicke and Coutré, 2020), in contrast to the depths where Pacific $(<600 \mathrm{~m})$ and Atlantic $(<500 \mathrm{~m})$ halibut overwinter (Loher and Seitz, 2008; Murphy et al., 2017), and the commonly held assumption is that Greenland halibut release their eggs at these depths (Alton et al., 1988; Sohn et al., 2010; Duffy-Anderson et al., 2013). Our results indicate that Greenland halibut may release eggs at depths that are much shallower than previously thought, possibly affecting interpretation of egg and larval incubation and distribution. Spawning rises identified for females in the winter consistently peaked just below the mixed layer, which in the Bering Sea is deeper

indicate that Greenland halibut in the BSAI region spawn from January through February, with eggs being released 217-326 $\mathrm{m}$ below the surface (inferred from interpolated apexes of spawning rises of females), although they normally inhabit deeper water. Because our study involved a small sample of individuals from the population and because tags recorded at intervals of 1-15 min, we believe that it is prudent to assume that eggs are released at a broader depth range of 200-350 m. The notions that Greenland halibut are total spawners and are capable of spawning annually are also supported by identification of singular spawning rises made by females in consecutive years. The depths at which females initiated spawning rises may provide evidence of depth (or site) fidelity. For example, a fish (tag no. 5282) began rises at depths of $859 \mathrm{~m}, 972 \mathrm{~m}$, and $886 \mathrm{~m}$ in 3 consecutive years, and another fish (tag no. 383) initiated rises at depths of 619 $\mathrm{m}, 526 \mathrm{~m}$, and $527 \mathrm{~m}$ in 3 consecutive years (Table 1).

The consistency in the time between annual spawning rises identified for females in this study was remarkably close to 1 year; therefore, the timing of spawning of an individual female likely can be predicted from the time it spawned the previous year. This hypothesis has been put and cooler during the winter than during other seasons, reaching depths of approximately $200 \mathrm{~m}$; a permanent halocline exists below the maximum depth of the mixed layer, and the subsurface temperature maximum is centered at 200-300 m (Johnson and Stabeno, 2017).

Because embryo development of Greenland halibut, and therefore the timing of the hatch, depends upon water temperature (Domínguez-Petit et al., 2013) and because temperature is correlated with depth, back-calculations of spawn timing from egg and larval development can be incorrect if assumptions of the depth at which spawning occurs are wrong. Another large deepwater flatfish species, the Pacific halibut, it has been assumed, spawns on the bottom (Bailey et al., 2008), although evidence of spawning rises indicate that eggs are plausibly released at depths higher in the water column (Seitz et al., 2005; Loher and Seitz, 2008). Results of analysis of archival tag data indicate that similar misspecification of spawning depth may be occurring for Greenland halibut, and this problem should be resolved in future modeling efforts.

The sex-specific differences observed in the spawning behavior of Greenland halibut in this study indicate that females spawn a single batch when fully developed and 


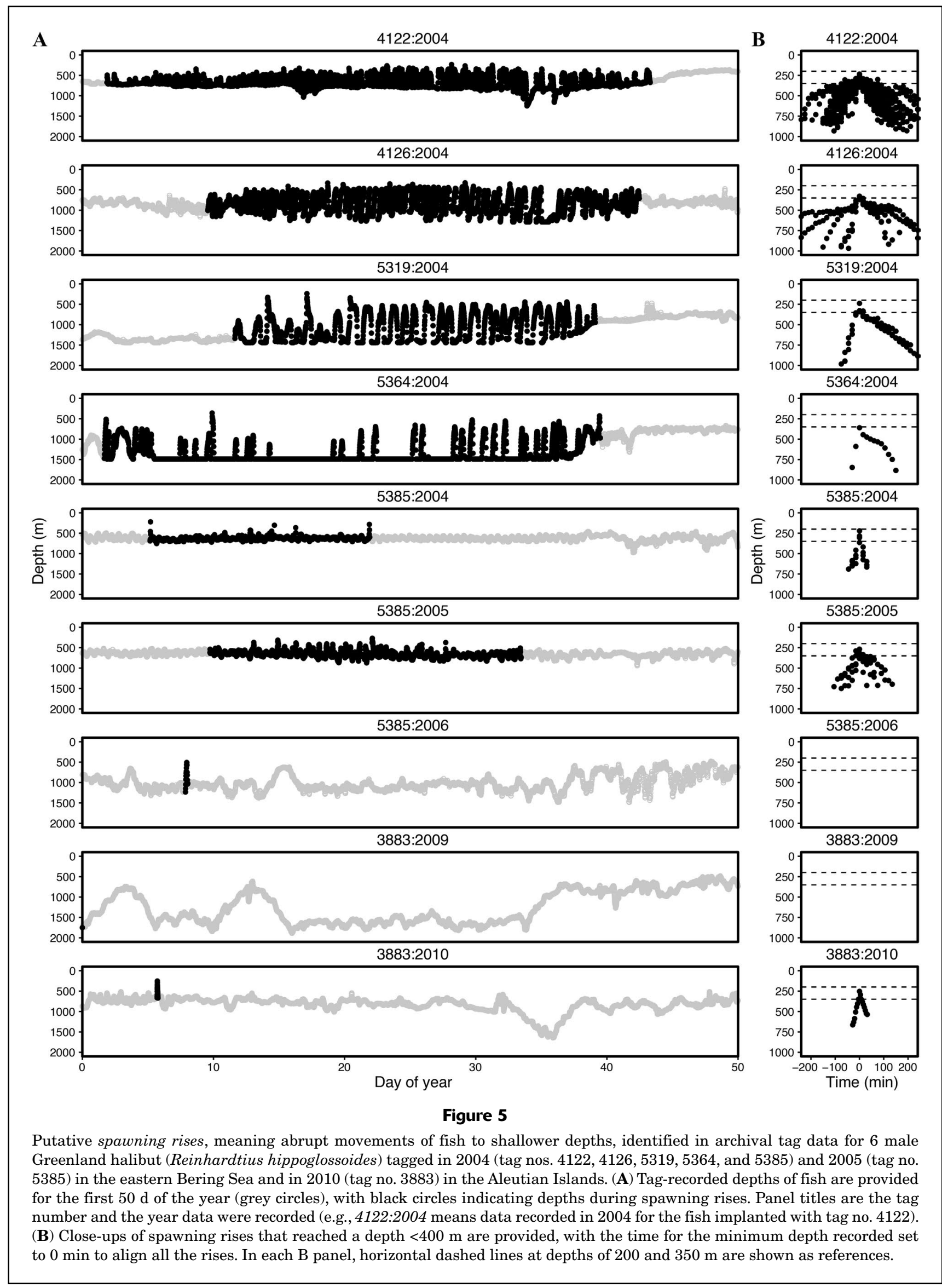



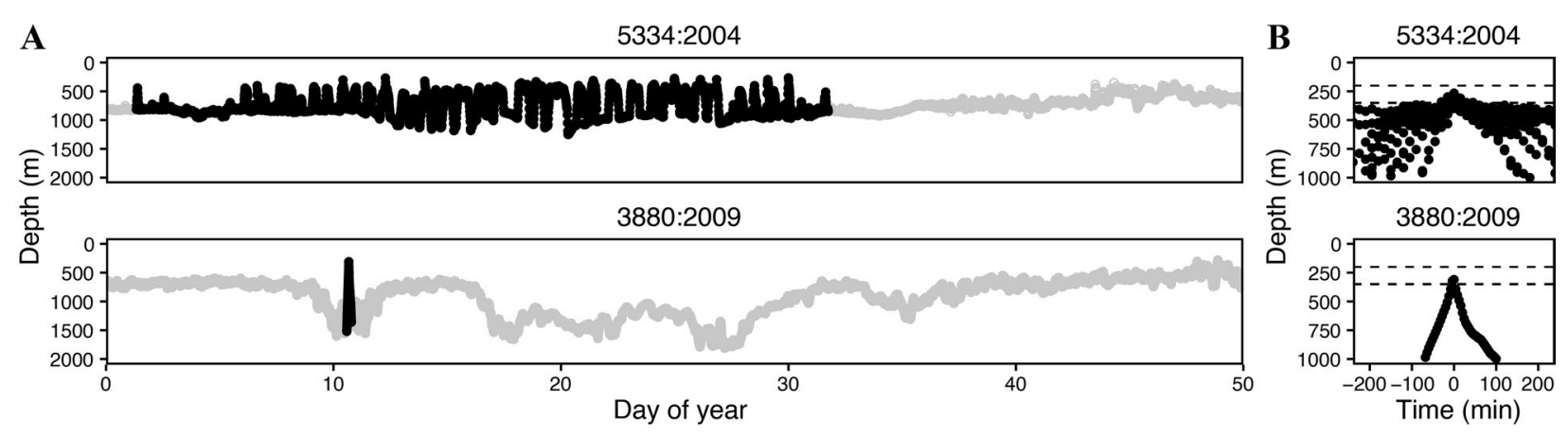

Figure 6

Putative spawning rises, meaning abrupt movements of fish to shallower depths, identified in archival tag data for 2 Greenland halibut (Reinhardtius hippoglossoides) of undetermined sex tagged in 2004 (tag no. 3880) in the eastern Bering Sea and in 2009 (tag no. 5334) in the Aleutian Islands. (A) Tag-recorded depths of fish are provided for the first $50 \mathrm{~d}$ of the year (grey circles), with black circles indicating depths during spawning rises. Panel titles are the tag number and the year data were recorded (e.g., 5334:2004 means data recorded in 2004 for the fish implanted with tag no. 5334). (B) Close-ups of spawning rises that reached a depth $<400 \mathrm{~m}$ are provided, with the time for the minimum depth recorded set to 0 min to align all the rises. In each B panel, horizontal dashed lines at depths of 200 and $350 \mathrm{~m}$ are shown as references.

that males have a prolonged spawning state during which their vertical activity increases. The single spawning rise means that females spawn once in a year and do not hydrate multiple batches of eggs, and this finding supports the results of recent studies that indicate that 2 cohorts of vitellogenic oocytes are not spawned in the same season (Kennedy et al., 2011). In a study of gonad development of Greenland halibut in the Barents and Norwegian Seas, males spawned over an extended period and females had a bimodal split between prespawning and postspawning (Albert et al. $^{2}$ ). The results of that study are consistent with our finding that males actively spawn for a protracted period and females actively spawn for a very narrow period. Sex-specific differences that have been identified for Pacific and Atlantic halibut are nearly identical to observations for Greenland halibut, with males having more sporadic and protracted spawning behavior relative to the abrupt rises of females (Loher and Seitz, 2008; Murphy et al., 2017). The increase in vertical movements of male Greenland halibut during this presumed spawning time identified in these studies and in our study contrasts with reported spawning activity of Atlantic cod (Gadus morhua): a tide is evident in depth profiles of males that sit in lekking arenas waiting for females to spawn (e.g., Meager et al., 2010).

These differences could also be used to infer sex for tagged Greenland halibut that did not have their sex determined but were at liberty through the winter. For example, one fish of undetermined sex had spawning activity with the expected prolonged, regular periodicity of typical

\footnotetext{
${ }^{2}$ Albert, O. T., E. M. Nilssen, A. Stene, A. C. Gundersen, and K. H. Nedreaas. 1998. Spawning of the Barents Sea/Norwegian Sea Greenland halibut (Reinhardtius hippoglossoides). ICES CM Doc. 1998/O:22, 19 p. [Available from website.]
}

male behavior, and another fish that did not have its sex determined had the isolated spawning rise of a female (Fig. 6). Previous research in which archival tags were used on Greenland halibut (e.g., Peklova et al., 2012) should be reexamined for evidence of these behaviors and their annual consistency, given that this study was focused on the BSAI region and that our results cannot be applied to all populations across the range of this species. Boje et al. (2014) made at least one reference to a Greenland halibut suddenly ascending from a depth of approximately $800 \mathrm{~m}$ up to a depth of $450 \mathrm{~m}$ within $1 \mathrm{~h}$ during November, a movement that appears similar to the presumed spawning rises we have described. Identification of the presence or absence of this singular annual spawning rise for female Greenland halibut in other regions would be informative.

The likelihood of a female Greenland halibut exhibiting spawning behavior may be delineated by length. The 2 females that did not have spawning rises were the smallest females recovered, at 68 and $71 \mathrm{~cm} \mathrm{FL}$, and the 3 females that did exhibit this spawning behavior were larger than $83 \mathrm{~cm}$ FL. We hypothesize that these smaller fish did not have spawning rises because they were not yet mature. It is possible that they did spawn without an obvious ascent like the larger fish, and additional research, such as deployment of the SeaTag-SP (Desert Star Systems, LLC, Monterey Bay, CA), which transmits a location and archival data when spawning occurs, could help clarify whether such small females are spawning with or without rises. Alternatively, a lack of spawning rises detected in archival tag data for the small Greenland halibut may not be associated with size and could be indicative of skipped spawning. Skipped spawning, when a mature fish does not spawn, occurs in many taxa, such as the Pacific halibut (Loher and Seitz, 2008), sablefish (Anoplopoma fimbria) (Rodgveller et al., 2016), and Sebastes species (Conrath, 2017). Skipped 
spawning has been suggested for Greenland halibut (Fedorov, 1971); however, this behavior seems an unlikely explanation because it would mean that these small fish were already mature at an even smaller size. Given the more recent interpretation of gonad development of female Greenland halibut and the lack of spawning evidence for small females, the $L_{50}$ currently used in stock assessments may be an underestimate, and the maturity classifications for Greenland halibut in the BSAI region should therefore be revisited.

Tagging research focused on spawning behavior should consider several aspects of study design. When archival tags have a temporal data resolution that is too coarse (e.g., hourly), they are unlikely to capture behaviors of short durations such as spawning (Fisher et al., 2017). Tag sampling intervals must be set appropriately to capture the behavior of interest. For spawning of large flatfish, 1-min intervals are appropriate, but if multiyear data are desirable, a longer interval may be necessary to extend battery life. Type of tag is another consideration; pop-off satellite archival tags are often chosen because fish do not need to be recaptured to retrieve data, whereas the use of archival tags that had to be implanted in fish in this study required a large number of tags to be deployed relative to the number of tags recovered with usable data. A drawback in several studies of spawning in which pop-off satellite archival tags were used is the lack of sex information associated with the tag data retrieved (unless the fish is recaptured and visually inspected); this issue could be remedied through genetic sampling at the time of release (e.g., Goetz et al., 2018). Tags that provide data that can be used to confirm these presumed behaviors are becoming available. The previously mentioned SeaTag-SP could be used to corroborate the assumption that spawning has occurred and to aid estimation of the location and timing of spawning.

\section{Conclusions}

Tagging studies can be used to generate and test hypotheses related to fish behavior; for example, analysis of tag data can determine spawning timing and location. Tag data also can be used in concert with data from other sources to provide a more complete view of the life history for large species that are difficult to sample. The findings from our analysis of data from tags implanted in Greenland halibut in the BSAI region are as follows: 1) spawning occurs in January and February; 2) eggs are released at depths of 200-350 m below the surface; 3) females are total spawners, releasing eggs only once during a year; and 4) a female can spawn in consecutive years. Data from deployment of additional tags could also support a revised $L_{50}$ for Greenland halibut based upon dimorphic rising behavior or could also be used to infer a minimum size at spawning, information that could aid in defining lengths in maturity tables. The use of archival tags should therefore be considered as a complement (when appropriate) to other methods when designing future research on fish behavior.

\section{Acknowledgments}

We would like to thank the numerous researchers, observers, and fishermen that have contributed to the successful tagging and recapture of Greenland halibut, including the captains and crews of the FV Ocean Prowler and FV Alaskan Leader for their contributions over many years tagging fish during Alaska Fisheries Science Center longline surveys. Thanks to J. Ianelli for providing some of the archival tag data and noting the potential of rises in spawning behavior. Thanks to B. Williams, M. Bryan, J. Lee, and 2 anonymous reviewers for suggestions that helped improve this manuscript.

\section{Literature cited}

Albert, O. T., E. M. Nilssen, A. Stene, A. C. Gundersen, and K. H. Nedreaase.

2001. Maturity classes and spawning behaviour of Greenland halibut (Reinhardtius hippoglossoides). Fish. Res. 51:217-228. Crossref

Albert, O. T., Y. Lambert, T. Vollen, C. Freitas, and L. Heggebakken. 2012. Distinguishing pelagic and demersal swimming of deepwater flatfish by recording of body angles. Am. Fish. Soc. Symp. 76:507-527.

Alton, M. S., R. G. Bakkala, G. E. Walters, and P. T. Munro.

1988. Greenland turbot Reinhardtius hippoglossoides of the eastern Bering Sea and Aleutian Islands region. NOAA Tech. Rep. NMFS 71, 31 p.

Bailey, K. M., A. A. Abookire, and J. T. Duffy-Anderson.

2008. Ocean transport paths for the early life history stages of offshore-spawning flatfishes: a case study in the Gulf of Alaska. Fish Fish. 9:44-66. Crossref

Boje, J., S. Neuenfeldt, C. R. Sparrevohn, O. Eigaard, and J. W. Behrens.

2014. Seasonal migration, vertical activity, and winter temperature experience of Greenland halibut Reinhardtius hippoglossoides in West Greenland waters. Mar. Ecol. Prog. Ser. 508:211-222. Crossref

Bryan, M. D., S. J. Barbeaux, J. Ianielli, D. Nichol, and J. Hoff. 2018. Assessment of Greenland turbot in the Bering Sea and Aleutian Islands, 97 p. In Stock assessment and fishery evaluation report for groundfish resources in the Bering Sea/Aleutian Islands region. North Pac. Fish. Manage. Counc., Anchorage, AK. [Available from website.]

Bulatov, O. A.

1983. Distribution of eggs and larvae of Greenland halibut, Reinhardtius hippoglossoides (Pleuronectidae), in the eastern Bering Sea. J. Ichthyol. 23:157-159.

Conrath, C. L.

2017. Maturity, spawning omission, and reproductive complexity of deepwater rockfish. Trans. Am. Fish. Soc. 146:495-507. Crossref

Cooper, D. W., K. P. Maslenikov, and D. R. Gunderson.

2007. Natural mortality rate, annual fecundity, and maturity at length for Greenland halibut (Reinhardtius hippoglossoides) from the northeastern Pacific Ocean. Fish. Bull. 105:296-304.

Cooper,W.T,L. R. Barbieri, M. D. Murphy, and S. K. Lowerre-Barbieri. 2013. Assessing stock reproductive potential in species with indeterminate fecundity: effects of age truncation and size-dependent reproductive timing. Fish. Res. 138:31-41. Crossref 
Domínguez-Petit, R., P. Ouellet, and Y. Lambert.

2013. Reproductive strategy, egg characteristics and embryonic development of Greenland halibut (Reinhardtius hippoglossoides). ICES J. Mar. Sci. 70:342-351. Crossref

Duffy-Anderson, J. T., D. M. Blood, W. Cheng, L. Ciannelli, A. C. Matarese, D. Sohn, T. C. Vance, and C. Vestfals.

2013. Combining field observations and modeling approaches to examine Greenland halibut (Reinhardtius hippoglossoides) early life ecology in the southeastern Bering Sea. J. Sea Res. 75:96-109. Crossref

D'yakov, Yu. P.

1982. The fecundity of the Greenland turbot, Reinhardtius hippoglossoides, (Pleuronectidae), from the Bering Sea. J. Ichthyol. 22:59-64.

Everson, I.

1994. Timescale of ovarian maturation in Notothenia coriiceps; evidence for a prolonged adolescent phase. J. Fish Biol. 44:997-1004. Crossref

Fedorov, K. Ye.

1968. Oogenesis and the sexual cycle of the Greenland halibut. Tr. Polyarn. Nauchno-Issled. Proektn. Inst. Morsk. Rybn. Kohoz. Okeanogr. 23:425-450.

1971. The state of the gonads of the Barents Sea Greenland halibut, Reinhardtius hippoglossoides (Walb.) in connection with failure to spawn. J. Ichthyol. 11:673-682.

Finn, R. N., G. C. Østby, B. Norberg, and H. J. Fyhn.

2002. In vivo oocyte hydration in Atlantic halibut (Hippoglossus hippoglossus); proteolytic liberation of free amino acids, and ion transport, are driving forces for osmotic water influx. J. Exp. Biol. 205:211-224. Crossref

Fisher, J. A. D., D. Robert, A. Le Bris, and T. Loher.

2017. Pop-up satellite archival tag (PSAT) temporal data resolution affects interpretations of spawning behaviour of a commercially important teleost. Anim. Biotelem. 5:21. Crossref

Goetz, F. W., A. J. Jasonowicz, and S. B. Roberts.

2018. What goes up must come down: diel vertical migration in the deep-water sablefish (Anoplopoma fimbria) revealed by pop-up satellite archival tags. Fish. Oceanogr. 27:127-142. Crossref

Gundersen, A. C., K. H. Nedreaas, O. S. Kjesbu, and O. T. Albert.

2000. Fecundity and recruitment variability of northeast Arctic Greenland halibut during 1980-1998, with emphasis on 1996-1998. J. Sea Res. 44:45-54. Crossref

Gundersen, A. C., J. Kennedy, A. Woll, I. Fossen, and J. Boje.

2013. Identifying potential Greenland halibut spawning areas and nursery grounds off East and South-western Greenland and its management implications. J. Sea Res. 75:110-117. Crossref

Johnson, G. C., and P. J. Stabeno.

2017. Deep Bering Sea circulation and variability, 2001-2016, from Argo data. J. Geophys. Res. Oceans 122:9765-9779. Crossref

Junquera, S., E. Román, J. Morgan, M. Sainza, and G. Ramilo.

2003. Time scale of ovarian maturation in Greenland halibut (Reinhardtius hippoglossoides, Walbaum). ICES J. Mar. Sci. 60:767-773. Crossref

Kennedy, J., and H. G. Ólafsson.

2019. Conservation of spawning time between years in lumpfish Cyclopterus lumpus and potential impacts from the temporal distribution of fishing effort. Fish. Manag. Ecol. 26:389-396. Crossref

Kennedy, J., A. C. Gundersen, and J. Boje.

2009. When to count your eggs: is fecundity in Greenland halibut (Reinhardtius hippoglossoides W.) down-regulated? Fish. Res. 100:260-265. Crossref
Kennedy, J., A. C. Gundersen, Å. S. Høines, and O. S. Kjesbu.

2011. Greenland halibut (Reinhardtius hippoglossoides) spawn annually but successive cohorts of oocytes develop over 2 years, complicating correct assessment of maturity. Can. J. Fish. Aquat. Sci. 68:201-209. Crossref

Kennedy, J., R. B. Hedeholm, A. C. Gundersen, and J. Boje.

2014. Estimates of reproductive potential of Greenland halibut (Reinhardtius hippoglossoides) in East Greenland based on an update of maturity status. Fish. Res. 154:73-81. Crossref

Le Bris, A., J. A. D. Fisher, H. M. Murphy, P. S. Galbraith, M. Castonguay, T. Loher, and D. Robert.

2018. Migration patterns and putative spawning habitats of Atlantic halibut (Hippoglossus hippoglossus) in the Gulf of St. Lawrence revealed by geolocation of pop-up satellite archival tags. ICES J. Mar. Sci. 75:135-147. Crossref

Loher, T., and A. C. Seitz.

2008. Characterization of active spawning season and depth for eastern Pacific halibut (Hippoglossus stenolepis), and evidence of probable skipped spawning. J. Northwest Atl. Fish. Sci. 41:23-36. Crossref

Manabe, H., and A. Shinomiya.

2001. Two spawning seasons and mating system of the bastard halibut, Tarphops oligolepis. Ichthyol. Res. 48:421424. Crossref

Marshall, C. T.

2009. Implementing information on stock reproductive potential in fisheries management: the motivation, challenges and opportunities. In Fish reproductive biology: implications for assessment and management (T. Jakobsen, M. J. Fogarty, B. A. Megrey, and E Moksness, eds.), p. 395-420. WileyBlackwell, Chichester, UK.

Meager, J. J., J. E. Skjæraasen, A. Fernö, and S. Løkkeborg.

2010. Reproductive interactions between fugitive farmed and wild Atlantic cod (Gadus morhua) in the field. Can. J. Fish. Aquat. Sci. 67:1221-1231. Crossref

Murawski, S. A., P. J. Rago, and E. A. Trippel.

2001. Impacts of demographic variation in spawning characteristics on reference points for fishery management. ICES J. Mar. Sci. 58:1002-1014. Crossref

Murphy, H. M., J. A. D. Fisher, A. Le Bris, M. Desgagnés,

M. Castonguay, T. Loher, and D. Robert.

2017. Characterization of depth distributions, temperature associations, and seasonal migrations of Atlantic halibut in the Gulf of St. Lawrence using pop-up satellite archival tags. Mar. Coast. Fish. 9:341-356. Crossref

Murua, H., and F. Saborido-Rey.

2003. Female reproductive strategies of marine fish species of the North Atlantic. J. Northwest Atl. Fish. Sci. 33:23-31. Crossref

Musienko, L. N.

1970. Reproduction and development of Bering Sea fishes. In Soviet fisheries investigations in the northeastern Pacific, part 5 (P. A. Moiseev, ed.), p. 161-224. [Translated by Isr. Program Sci. Transl., 1972.] [Available from Natl. Tech. Inf. Serv., 5301 Shawnee Rd., Alexandria, VA 22312, as TT 71-50127.]

Peklova, I., N. E. Hussey, K. J. Hedges, M. A. Treble, and A. T. Fisk. 2012. Depth and temperature preferences of the deepwater flatfish Greenland halibut Reinhardtius hippoglossoides in an Arctic marine ecosystem. Mar. Ecol. Prog. Ser. 467:193205. Crossref

Rideout, R. M., D. M. Maddock, and M. P. M. Burton.

1999. Oogenesis and the spawning pattern in Greenland halibut from the North-west Atlantic. J. Fish Biol. 54:196-207. Crossref 
Rideout, R. M., M. J. Morgan, Y. Lambert, A. M. Cohen, J. H. Banoub, and M. Treble.

2012. Oocyte development and vitellogenin production in Northwest Atlantic Greenland halibut Reinhardtius hippoglossoides. J. Northwest Atl. Fish. Sci. 44:15-30.

Rodgveller, C. J., J. W. Stark, K. B. Echave, and P.-J. F. Hulson. 2016. Age at maturity, skipped spawning, and fecundity of female sablefish (Anoplopoma fimbria) during the spawning season. Fish. Bull. 114:89-102. Crossref

Seitz, A. C., B. L. Norcross, D. Wilson, and J. L. Nielsen.

2005. Identifying spawning behavior in Pacific halibut, Hippoglossus stenolepis, using electronic tags. Environ. Biol. Fishes 73:445-451. Crossref

Serebryakov, V. P., A. K. Chumakov, and I. I. Tevs.

1992. Spawning stock, population fecundity and year-class strength of Greenland halibut (Reinhardtius hippoglossoides) in the Northwest Atlantic, 1969-88. J. Northwest Atl. Fish. Sci. 14:107-113.

Siwicke, K. A., and K. Coutré.

2020. Periodic movements of Greenland turbot Reinhardtius hippoglossoides in the eastern Bering Sea and Aleutian Islands. Fish. Res. 229:105612. Crossref

Smidt, E

1969. The Greenland halibut, Reinhardtius Hippoglossoidis (Walb.), biology and exploitation in Greenland waters. Medd. Dan. Fisk. Havunders. N.Y. Ser. 6(4):79-148.

Sohn, D., L. Ciannelli, and J. T. Duffy-Anderson. 2010. Distribution and drift pathways of Greenland halibut (Reinhardtius hippoglossoides) during early life stages in the eastern Bering Sea and Aleutian Islands. Fish. Oceanogr. 19:339-353. Crossref
St-Pierre, G.

1984. Spawning locations and season for Pacific halibut. Int. Pac. Halibut Comm., Sci. Rep. 70, 36 p. [Available from website.]

Stene, A., A. C. Gundersen, O. T. Albert, K. H. Nedreaas, and P. Solemdal.

1999. Early development of Northeast Arctic Greenland halibut (Reinhardtius hippoglossoides). J. Northwest Atl. Fish. Sci. 25:171-177.

Trippel, E. A.

1999. Estimation of stock reproductive potential: history and challenges for Canadian Atlantic gadoid stock assessments. J. Northwest Atl. Fish. Sci. 25:61-81.

Vinnikov, K. A., R. C. Thomson, and T. A. Munroe.

2018. Revised classification of the righteye flounders (Teleostei: Pleuronectidae) based on multilocus phylogeny with complete taxon sampling. Mol. Phylogenet. Evol. 125:147-162. Crossref

Wilmers, C. C., B. Nickel, C. M. Bryce, J. A. Smith, R. E. Wheat, and V. Yovovich.

2015. The golden age of bio-logging: how animal-borne sensors are advancing the frontiers of ecology. Ecology 96:1741-1753. Crossref

Wright, P. J., and E. A. Trippel.

2009. Fishery-induced demographic changes in the timing of spawning: consequences for reproductive success. Fish Fish. 10:283-304. Crossref 